\title{
Studies on Mechanical and Physicochemical Properties of Polymer Gels
}

\author{
Kenji URAYAMA \\ Department of Materials Chemistry, Kyoto University \\ Nishikyo-ku, Kyoto 615-8510, Japan
}

\begin{abstract}
The three topics in our study are reviewed in the present paper: (1) molecular understandings of rubber elasticity of end-linked polymer networks and the dynamics of trapped guest chains; (2) elastomers with remarkable extensibility or high damping insensitive to both frequency and temperature via topology control of polymer networks; (3) phase transition in polymer network systems such as sol-gel transition and volume phase transition driven by nematicisotroptic transition. On the basis of the biaxial elongation data of end-linked polydimethylsiloxane (PDMS) networks, the form of the strain energy density function is evaluated, and the five entanglement models of rubber elasticity are unambiguously assessed. It is shown that the dynamics of linear guest chains trapped in crosslinked networks obey the reptation concept. A dramatic slowing down of the reptation is observed in the host network whose mesh size is smaller than the entanglement spacing. The deswollen networks, prepared by end-linking long precursors in the diluted state and removing the solvent, exhibit a marked extensibility over $3000 \%$ as well as a very weak strain dependence of stress. These features stem from a small amount of trapped entanglement and a compact conformation of network chains. The damping of irregular networks containing many pendant chains increases with the amount of pendant chains. The damping is very weak dependent of temperature and frequency as a result of a slow viscoelastic relaxation of irregular network structures. The nematic networks swollen in nematic or isotropic solvents undergo a phase transition between the swollen isotropic and shrunken nematic states.
\end{abstract}

Key Words: Rubber elasticity / Biaxial elongation / Reptation / Damping / Volume phase transition

\section{高分子ゲルのカ学的および物理化学的性質に関する研究}

\author{
浦山 健治
}

（原稿受理：2005年9月 5 日）

\section{1. はじめに}

高分子ゲルは三次元網目構造に起因するユニークな物性 を示すソフトマテリアルである. ゲルの構造と物性は, 広範 な応用の可能性も含めて盛んに研究されてきた。しかし，こ れまでの研究では網目構造が十分にキャラクタライズされ ていなかったため, ゲルの物性の分子論的解釈に不明な点が 多く残されていた. 著者は, 末端架橋法を用いることにより, 網目鎖長および架橋点の分岐度が制御されたゲルを合成し, その力学物性の分子論的解析とともに, 機能性エラストマー の分子設計を行ってきた. また, ゾルーゲル転移, および夜 晶相転移を駆動力とした体積相転移などのゲルの相転移現 象に関する研究を進めてきた. 今回の奨励賞の受賞対象と なった研究は以下の通りである。

(1) 末端架橋ゲルを用いたゴム弾性およびゲスト鎖のダイ ナミクスの分子論的研究.

京都大学大学院工学研究科材料化学専攻

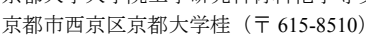

Phone: +81-75-383-2454

Fax: $+81-75-383-2458$

E-mail: urayama@rheogate.polym.kyoto-u.ac.jp
(2) 網目のトポロジー制御による高伸長性および高ダンピン グゲルの創製.

(3) ゲルの相転移現象に関する研究.

本稿では，(1)と(2)について詳しく説明し，(3)については 概要を紹介する程度にとどめる.

\section{2.末端架橋法によるゲルの作製}

ゴムの加硫や反応性モノマーの重合に代表される一般的 な架橋法では, 架橋点は系にランダムに生成し網目鎖長（化 学架橋点間の鎖長）には広い分布が生じる. また, 平均網目 鎖長や架橋点密度などの網目構造パラメータを反応条件の みから精度良く評価できない. 架橋剤の仕込夕濃度からこれ らの構造パラメータを概算することがあるが，この概算は架 橋反応が $100 \%$ 進行すること（現実には不可能であろう）を前 提としている. 網目構造パラメータは架橋反応のわずかな不 完全性にも非常に大きく影響をうけるため ${ }^{1-3)}$, 物性の分子論 的解釈を目的とした研究にはこのような概算值は不適当で ある。

末端架橋法は, 既知の分子量のプレカーサ鎖の両末端を多 
官能性架橋剂と反応させる方法である. 化学架橋点間分子量 $\left(M_{\mathrm{c}}\right)$ はプレカーサ鎖の分子量 $\left(M_{\mathrm{p}}\right)$ によって制御でき, 反応の 不完全性を考慮した構造パラメータの值を未反応物の量から 評価できるため，末端架橋系はモデル網目系といわれる. 1-3) 著者らは両末端にビニル基をもつポリジメチルシロキサン (PDMS)をプレカーサ鎖として用い， Si-H基をもつ3もしくは 4官能性低分子架橋剤とのヒドロシリル化反応により PDMS ゲルを作製した。

\section{3. 末端架橋ゲルを用いたゴム弾性およびゲスト鎖の ダイナミクスの分子論的研究}

\section{1 二軸伸長測定によるゴム弾性の解析 ${ }^{4-8)}$}

小さな力で可逆的な大変形を示すゲル（エラストマー）の ゴム弾性は他の材料には見られない物性であり，高分子網目 構造に由来する代表的な特性である. エラストマーの応力一 ひずみ挙動を支配する弾性自由エネルギー $W$ (ひずみエネル ギー密度関数とも呼ばれる）の理解は, ゴム弾性の研究の重 要課題のひとつである.Wの関数形が既知であれば任意の変 形の力学応答を知ることができる. 複雑な変形下のゴムの力 学応答を知るために有限要素法のシミュレーションが盛ん に行われているが, その精度は用いる $W$ 関数の信頼性次第と いっても過言ではない. このため, $W$ 関数の研究は学問的な 観点からだけではなく, 工業的応用の立場からも非常に重要 である。

$W$ 関数は未知であるので, 実際の応力ーひずみ関係を記述 する $W$ 関数を現象論的に推定する, もしくは網目のエントロ ピー弾性の分子論的考察から $W$ 関数を導出する, という二つ の立場がある. $W$ 関数はこの両面から精力的に研究されてき たが，その理解は未だに不十分なままである。これまでの $W$ の実験的研究の主な問題点として, (i) 限られた変形様式（一 軸伸長・圧縮試験）のデータに頼った解析, (ii)試料の網目構 造の不完全なキャラクタリゼーション, が挙げられる. (i) は 以前から指摘されているにもかかわらず9,10), 軽視されてきた 問題である．一軸伸長や圧縮変形は簡便な測定であるが，Fig. 1 に示すようにエラストマーが可能な変形のほんの一部にす ぎない. 一軸変形のデータのみから $W$ 関数の理論を検証した り関数形を推定する試みは,「森の一部だけを見て森全体の 様子を把握しようとする」ようなもので方法論自体に無理が あり, 誤った結論を導く可能性が極めて高い. 実際, 一軸変 形に限定すれば検証が甘くなるため, ほとんどの理論が実験 データを（みかけ上）よく記述できてしまい，様々なゴム弾 性分子論が乱立する原因になっている．また，一軸変形デー タのみから $W$ を現象論的に推定寸る試みがあるが（有名な例 としてMooney-Rivlinプロット), 推定された $W$ 予測する二 軸変形挙動は実際の挙動とかけ離れており8,10,11), その手法に 問題があるのは明らかである. (ii) は，分子論から導かれた $W$ の検証において特に重要である。前項で述べたように，一般 的な架橋法では, 架橋点は系にランダムに分布し網目鎖長に 広い分布が生じるだけでなく, 平均網目鎖長や架橋点密度の 信頼できる值を物性測定とは独立に求めることはできない. ランダム架橋された試料の応力ーひずみデータを用いて理論 を検証する際は, これらの構造パラメータをフィッティング パラメータとして用いる場合もあり，導かれる結論は極めて 曖昧になってしまう。 著者らは上記の(i) と(ii)の問題を考慮し, 未端架橋法によっ て網目構造がキャラクタライズされたゲル試料を作製し，広 いひずタ域の応力ーひずみデータを得るために一軸変形だ けでなく二軸伸長測定を行った。用いたプレカーサPDMS 鎖 の分子量 $\left(M_{\mathrm{w}}=8.95 \times 10^{4}\right)$ は絡み合い点間分子量 $\left(M_{\mathrm{e}}=8.1 \times 10^{3}\right)$ より十分に大きく，化学架橋点よりも網目中にトラップされ た絡み合い（trapped entanglement）の方が数的に支配的な網目 が形成される. trapped entanglementは, 未架橋高分子メルト中 などの絡み合いとは異なり, 架橋点が存在するために永久に 緩和できず平衡状態でも網目の弾性に寄与する。 ${ }^{12,13)}$ 各分子 論の大きな違いはtrapped entanglement のゴム弾性への寄与の モデル化にあるので，理論の優劣をより明確にするためには このような試料が適している.

Fig. 1に示すように様々な $\lambda_{1} と \lambda_{2}$ の組み合わせで二軸伸長変 形を行うと，非圧縮性のエラストマーの可能なひずみ域を全 てカバーすることができる、二軸伸張測定はBISS-0404（岩本 製作所）を用い，一定温度 $40{ }^{\circ} \mathrm{C}$ で行った。 pre-conditioning して, 予備実験で求めた最大伸張比 $\left(\lambda_{\text {max }}\right)$ まで試料を等二軸伸 張した後, 自然長まで戻す操作を数回繰り返した。 このpreconditioningの後, $\lambda_{\text {max }}$ まで等二軸伸張し, $\lambda_{1}=\lambda_{2}=\lambda_{\text {max }}$ において ひずみを保持し，力の時間変化がほぼ無視できる30分後の擬 平衡応力 $\sigma_{1}$ と $\sigma_{2}$ を測定した. $\lambda$ と $\lambda$ をを逐次減少させ， $\sigma_{1}, \sigma_{2}$ を $\lambda_{1}, \lambda_{2}$ の関数として測定した.また，二軸伸張測定と同一の 試料を用いて一軸伸張および圧縮測定を行った。

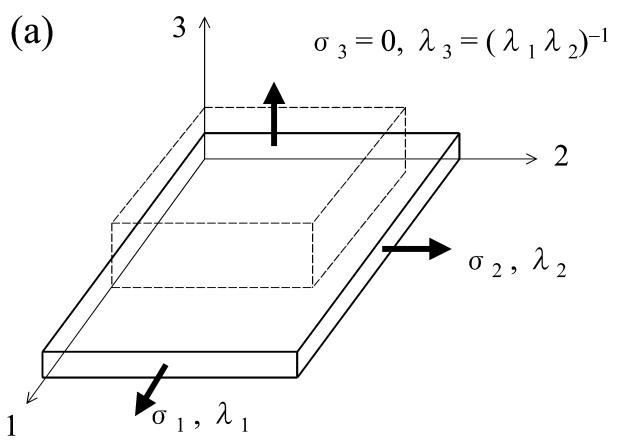

(b)

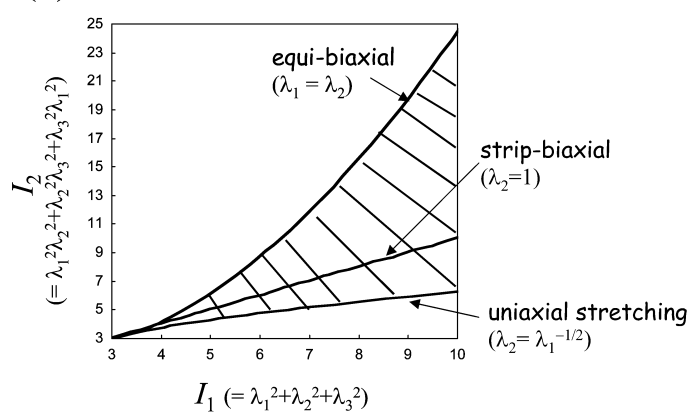

Fig. 1. (a) Schematics for biaxial stretching of elastomers. $\lambda_{\mathrm{i}}$ and $\sigma_{\mathrm{i}}$ denote the principal ratio and stress along $i$-axis, respectively. (b) The relations of $I_{1}$ and $I_{2}$ for equi-biaxial (uniaxial compression), strip-biaxial and uniaxial stretching for incompressible materials $\left(\lambda_{i} \lambda_{2} \lambda_{3}=1\right)$. The hatched area stands for the physically accessible region of incompressible materials. 
Fig. 2 に網目濃度が $70 \mathrm{wt} \%$ のゲルの各変形下の擬平衡工学 応力 $(\sigma)$ と軸比 $(\lambda)$ の関係を示す.1) 添字1は伸びが大きい方の 主軸方向を表す. 図中の $\square, \triangle$ は等二軸伸張 $\left(\lambda_{1}=\lambda_{2}\right)$ および一 軸伸張 $\left(\lambda_{2}=\lambda_{1}^{-1 / 2}\right)$ のデータを示す. $\lambda_{2}=1$ の伸長変形は純ずり （一軸拘束二軸）変形に相当する.

得られた応力ーひずみデータをもとに $W$ の関数形をRivlinSaunders(R-S) 法 ${ }^{14)}$ によって推定した. 一般的に，Wは変形テ ンソルの不変量 $I_{1}, I_{2}$ の関数として表される.

$$
\begin{aligned}
& W=W\left(I_{1}, I_{2}\right) \\
& I_{1}=\lambda_{1}{ }^{2}+\lambda_{2}{ }^{2}+\lambda_{3}{ }^{2} \\
& I_{2}=\lambda_{1}{ }^{2} \lambda_{2}{ }^{2}+\lambda_{2}{ }^{2} \lambda_{3}{ }^{2}+\lambda_{3}{ }^{2} \lambda_{1}{ }^{2}
\end{aligned}
$$

ここで第3 不変量 $I_{3}=\lambda_{1}{ }^{2} \lambda_{2}{ }^{2} \lambda_{3}{ }^{2}$ は, 系が非圧縮性 $\left(\lambda_{1} \lambda_{2} \lambda_{3}=1\right)$ なら ば変形によらず定数 1 であり $W$ の変数として含めない. この 試料のポアソン比は $0.5002 \pm 0.0005$ であり 4$)$, 非圧縮性とみな せる. 二軸伸張下の忘力ー伸び関係は, $W の I_{1}, I_{2}$ に関する偏 微分量 $\partial W / \partial I_{1}, \partial W / \partial I_{2}$ と次のような関係がある.

$$
\begin{aligned}
& \frac{\partial W}{\partial I_{1}}=\frac{1}{2\left(\lambda_{1}^{2}-\lambda_{2}^{2}\right)}\left[\frac{\lambda_{1}^{3} \sigma_{1}}{\lambda_{1}^{2}-\left(\lambda_{1} \lambda_{2}\right)^{-2}}-\frac{\lambda_{2}^{3} \sigma_{2}}{\lambda_{2}^{2}-\left(\lambda_{1} \lambda_{2}\right)^{-2}}\right] \\
& \frac{\partial W}{\partial I_{2}}=\frac{-1}{2\left(\lambda_{1}^{2}-\lambda_{2}^{2}\right)}\left[\frac{\lambda_{1} \sigma_{1}}{\lambda_{1}^{2}-\left(\lambda_{1} \lambda_{2}\right)^{-2}}-\frac{\lambda_{2} \sigma_{2}}{\lambda_{2}^{2}-\left(\lambda_{1} \lambda_{2}\right)^{-2}}\right]
\end{aligned}
$$

R-S 法は, 式(2) と(3)を用いて $\left(\lambda_{1}, \lambda_{2}, \sigma_{1}, \sigma_{2}\right)$ の実験データを $\left(I_{1}, I_{2}, \partial W / \partial I_{1}, \partial W / \partial I_{2}\right)$ に変換し $, \partial W / \partial I_{1}, \partial W / \partial I_{2}$ を $I_{1}, I_{2}$ の関数と して求め, これを積分してWを得る手法である.

Fig. 2 のデータから求めた $\partial W / \partial I_{1}$ と $\partial W / \partial I_{2}$ の $\left(I_{1}-3\right),\left(I_{2}-3\right)$ に 対する 3 次元プロットをFig. 3 に示す. 未変形状態で $I_{1}=I_{2}=3$ であることを考慮し, $\left(I_{1}-3\right)$ およ゙ $\left(I_{2}-3\right)$ を変数としている.ひ ずみが小さい領域を除けば, 各偏微分量のデータ点はそれぞ れある平面上にあり, 各偏微分量の $\left(I_{1}-3\right)$ および $\left(I_{2}-3\right)$ に対す る依存性は線形であることがわかる. これを満たす $W\left(I_{1}, I_{2}\right)$ と して以下の式が求められる.

$$
\begin{aligned}
W= & C_{10}\left(I_{1}-3\right)+C_{01}\left(I_{2}-3\right)+C_{11}\left(I_{1}-3\right)\left(I_{2}-3\right) \\
& +C_{20}\left(I_{1}-3\right)^{2}+C_{02}\left(I_{2}-3\right)^{2}
\end{aligned}
$$

各係数は, 各平面の勾配と切片から一意的に決めることがで きる.このWから計算された応力一伸び関係（Fig. 2の実線） は, 二軸伸張データだけでなく, Wの推定に用いていない (式 (3)が不定形になる) 等二軸伸張, 一軸伸張および一軸圧縮の データとも良く一致しており, 式(4)の妥当性を確認できる. 網目作製濃度すなわち網目中の絡み合い量を変化させた PDMS ゲルについても同様の検討を行った。 ${ }^{6}$ 式(4)の各係数 は高次項になるほど濃度依存性が大きく, 低濃度では高次項 の寄与は急激に減少した。このことから，Wの高次のひずみ 項は網目鎖間の絡み合いに由来することが示唆される.

ゴム弾性はエントロピー由来であるから, 原理的には変形 に伴う構成高分子鎖の形態数の変化を計算すれば, $W$ 求め
ることができる，ガウス鎖から成る網目のWは，網目鎖間の 相互作用を無視した場合,

$$
W=C T\left(\lambda_{1}^{2}+\lambda_{2}^{2}+\lambda_{3}^{2}-3\right)=C T\left(I_{1}-3\right)
$$

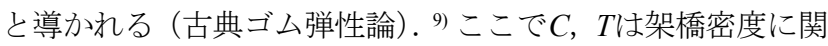
連した定数および絶対温度である. エラストマーの応力は, 同じくエントロピー由来である気体の圧力に例えられるが,

(a)

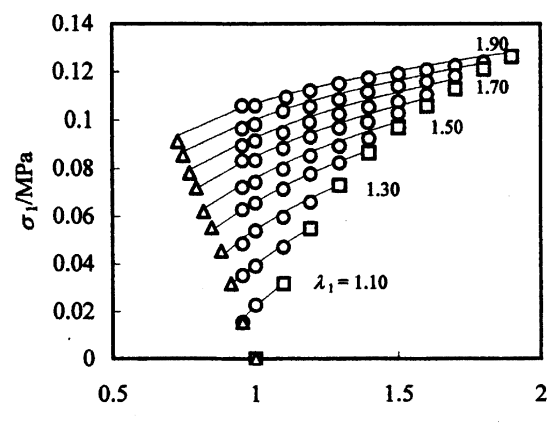

(b) $\quad \lambda_{2}$

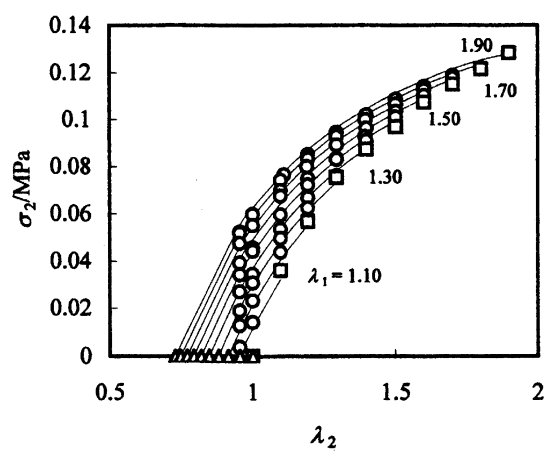

Fig. 2. Quasi-equilibrium stresses (a) $\sigma_{1}$ and (b) $\sigma_{2}$ of an end-linked PDMS network under uniaxial and biaxial stretching as a function of $\lambda_{2}$. The rectangular and triangular symbols represent the data for equi-biaxial and uniaxial stretching, respectively. The solid lines stand for the stress-elongation curves calculated from Eq. (4).

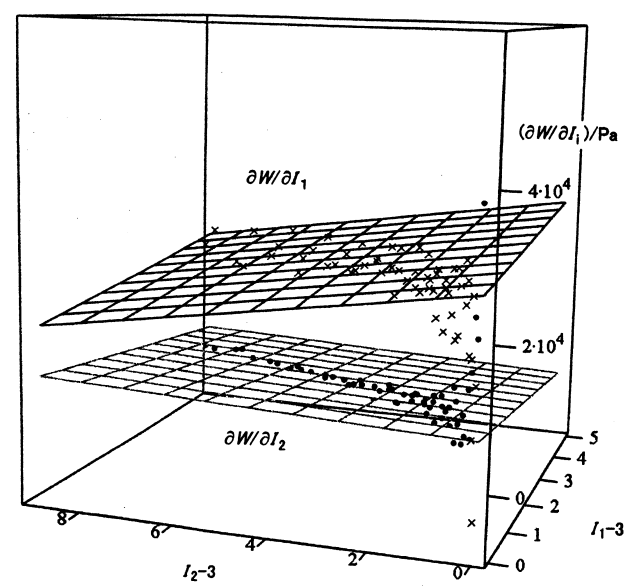

Fig. 3. Derivatives $\partial W / \partial I_{1}$ and $\partial W / \partial I_{2}$ as a function of $\left(I_{1}-3\right)$ and $\left(I_{2}-3\right)$ for the data in Fig. 2. 
それに習えば古典ゴム弾性論は理想気体に相当する理想ゴ ムというべき系を対象としている。古典論では式(5)より $\partial W / \partial I_{1}=C$ (定数), $\partial W / \partial I_{2}=0$ となるが, 以前から知られている ように (Fig. 3参照) 実在のゴムの挙動とは一致しない.この 不一致の主因は, 実在系に多数存在する trapped entanglementに よる分子間相互作用や大変形時の網目鎖の伸びきり効果 (非 ガウス鎖効果）を古典論が考慮していないことにある. 近年 のゴム弾性分子論は，これらの効果のモデル化に主眼を置い ている．これまでの理論の検証の多くは適当なゴムの一軸変 形の応力ーひずみデータを用いているが，前述の理由でどの 理論もある程度フィッティングできてしまうので, 理論の優 劣を見分けることは難しい. 著者らは, Fig. 1の末端架橋PDMS ゲルの一軸および二軸変形データと反応から決定した網目 構造パラメータを用いて, 代表的な5種の分子論 ${ }^{15-19)}$ の予測と の比較を行った. 5) 各理論の検証結果はここでは網羅できな いので, 実験結果を最もよく再現したslip-link model ${ }^{17)} の$ フィッティングの結果を Fig. 4 に示寸. slip-link model はパラ メータとして trapped entanglementをモデル化した slip-linkの可 動度 $\eta$ と網目鎖の極限伸びの逆数 $\alpha$ を含む. $\eta$ および $\alpha$ は網目 構造パラメータと次式のような関係がある。 ${ }^{20)}$

$$
\begin{aligned}
& \eta \approx M_{\mathrm{e}} / M_{\mathrm{c}} \\
& \alpha \approx N_{\mathrm{j}}^{-1 / 2}
\end{aligned}
$$

(a)

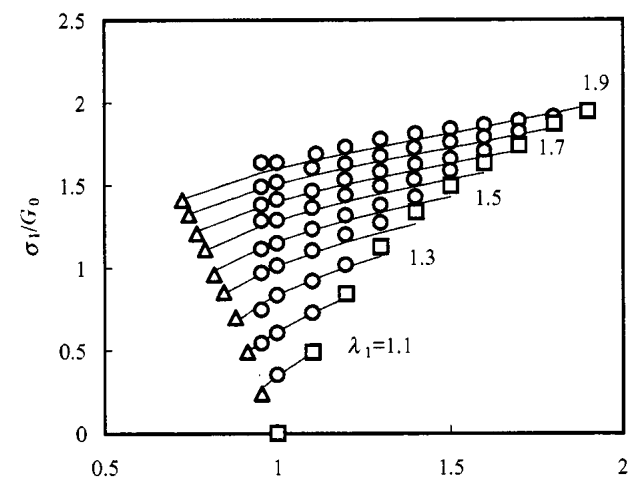

(b)

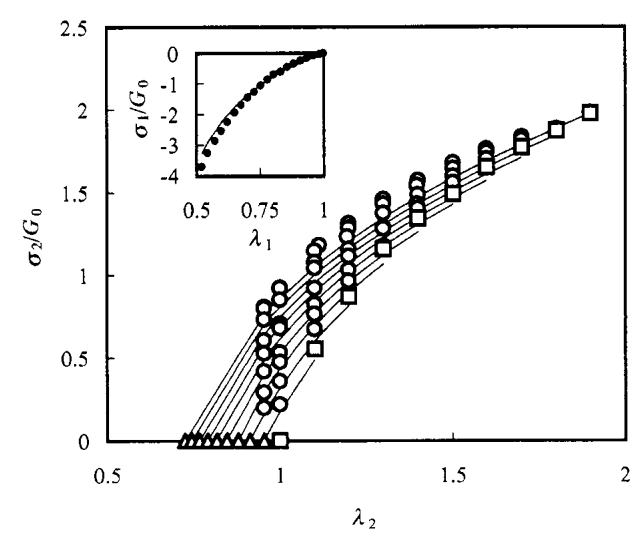

Fig. 4. Comparisons of the biaxial deformation data in Fig. 2 with the prediction of the slip-link model. The inset shows the comparison for the data of uniaxial compression.
$M_{\mathrm{c}}, N_{\mathrm{j}}$ はそれぞれ化学架橋点閒の分子量, 弾性的に有効な架 橋点（化学架橋点と trapped entanglementを区別しない）間の Kuhn segment数である. 式(6) と網目構造パラメータの值から

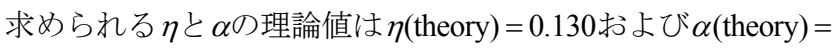
0.161 であるのに対し, 応力ーひずみデータのフィッティング から求めた值は $\eta=0.120$ および $\alpha=0.160$ であり，両者の一致 は良好である。このように, slip-link modelは広いひずみ域の 応力ーひずみ挙動をよく記述し, フィッティングに用いたモ デルパラメータ值もそれとは独立に網目構造から求めた值 とよく一致している. また, trapped entanglementの量が異なる PDMS ゲルの二軸変形データについても, slip-link model の予 測は良い一致を示した。 ${ }^{7)}$

\section{2 ゲスト鎖の粘弾性緩和の研究 21)}

メッシュサイズ $\left(M_{\mathrm{x}}\right)$ が制御できる末端架橋ゲルの特徵を 利用し，網目にトラップされた線状ゲスト鎖の粘弾性緩和 を $M_{\mathrm{x}}$ およびゲスト鎖の分子量 $\left(M_{\mathrm{g}}\right)$ を変数として調べた. 固 定された網目マトリックス中の高分子鎖の運動は, tube model (reptation model) ${ }^{22)}$ の原点でもある．過去にもゲス卜鎖を含ん だ架橋ゴムの粘弾性の研究例はあるが23-26)，ゴムマトリック スとゲス卜鎖の化学種が異なっていたり，ランダム架橋され たホスト網目の $M_{\mathrm{x}}$ に広い分布があることなどが実験結果の 解釈を複雑にしていた。本研究では, $M_{\mathrm{e}}\left(=8.1 \times 10^{3}\right)$ よりも十 分に大きいあるいは小さい分子量 $\left(M_{\mathrm{n}}=8.40 \times 10^{4}\right.$ あるいは $\left.4.55 \times 10^{3}\right)$ のプレカーサPDMS 鎖を用い，メッシュの大半が trapped entanglementである $M_{\mathrm{x}} \approx M_{\mathrm{e}}$ のホスト網目 $(\mathrm{NL})$ と，メッ シュが $M_{\mathrm{e}}$ よりも小さい $\left(M_{\mathrm{x}}<M_{\mathrm{e}}\right)$ ホスト網目 $(\mathrm{NS})$ を作製した. 分子量分布の狭い非反応性 PDMS 鎖(15 wt \%) とプレカーサ PDMS 鎖の混合物の未端架橋反応を行い，ゲスト鎖がトラッ プされたPDMSゲルを合成した。

Fig. 5 に異なる $M_{\mathrm{g}}$ のゲスト鎖を含むNLの動的ヤング率 $\left(E^{\prime}\right)$ と損失正接 $\tan \delta$ の角周波数 $(\omega)$ 依存性を示寸. NLのメッシュ は trapped entanglementによって支配的に形成されており, 平衡 弾性率から求めた $M_{\mathrm{x}}$ は $M_{\mathrm{x}}=1.1 M_{\mathrm{e}}$ である。ゲスト鎖の緩和は $\tan \delta$ の周波数依存性に明瞭なピークとして現れ，ピークの周 波数 $\left(\omega_{\text {peak }}\right)$ は $M_{\mathrm{g}}$ の増加とともに低周波数側にシフトしてい

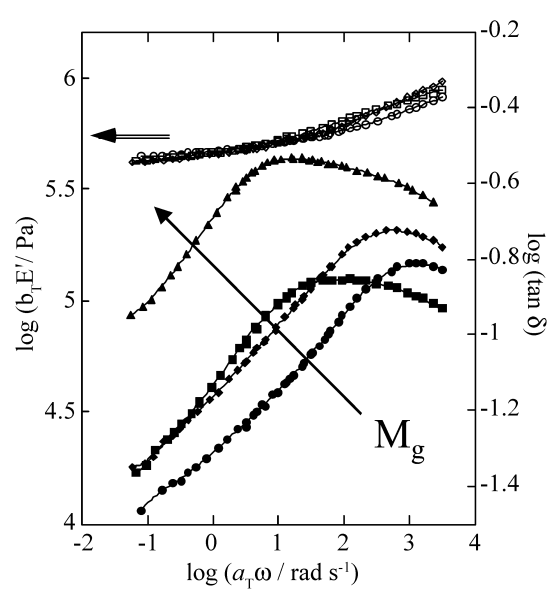

Fig. 5. Frequency $(\omega)$ dependence of $E^{\prime}$ and $\tan \delta$ for the end-linked PDMS networks NL containing the guest linear PDMS with different molecular masses $\left(M_{\mathrm{g}}\right)$. 
る. ゲスト鎖の緩和時間 $\tau_{\mathrm{g}}$ を $\tau_{\mathrm{g}}=\omega_{\text {peak }}{ }^{-1}$ から評価し, $M_{\mathrm{g}}$ 依存性 を検討した(Fig. 6). 網目中のゲスト鎖の最長緩和時間 $\tau_{\mathrm{L}}$ につ いて, tube modelは $\tau_{\mathrm{L}} \sim M_{\mathrm{g}}{ }^{3}$ を予測し, 鎖長摇らぎ(contour length fluctuation)を考慮した修正tube modelの予測は22)

$$
\tau_{\mathrm{L}}=\frac{b^{2} \zeta_{0} M_{\mathrm{g}}{ }^{3}}{M_{\mathrm{X}} M_{0}{ }^{2} \pi^{2} k T}\left[1-1.3\left(\frac{M_{\mathrm{X}}}{M_{\mathrm{g}}}\right)^{0.5}\right]^{2}
$$

$b, M_{0}, \quad \zeta_{0}$ はモノマーの大きさ, モノマーユニットの分子量, モノマーの摩擦係数である. 図からわかるように, $\tau_{\mathrm{g}}$ は $\tau_{\mathrm{L}}$ の 計算值にかなり近く, $M_{\mathrm{g}}$ 依存性は式(7)にほぼ従っている. NS $\left(M_{\mathrm{x}}=0.8 M_{\mathrm{e}}\right)$ 中のゲス卜鎖の $\tau_{\mathrm{g}}$ の $M_{\mathrm{g}}$ 依存性も Fig. 6に示す. $\tau_{\mathrm{g}}$ の $M_{\mathrm{g}}$ 依存性はtube model の予測とほぼ一致するが, 同一の $M_{\mathrm{g}}$ の $\tau_{\mathrm{g}}^{\mathrm{g}} \mathrm{NL}$ とS で比較すると NSでは4桁ほども大きくなってい る. 式(7)は $M_{\mathrm{x}}$ の減少に伴って $\tau_{\mathrm{g}}$ が増加する挙動(strangulation effect $)^{27)}$ 予測しているが, その効果は $1 / M_{\mathrm{x}}$ にすぎず観察され たレプテーションの著しい遅延を説明できない. $M_{\mathrm{e}}$ よりも小 さいメッシュの網目中では, レプテーションは“entropic barrier”と呼ばれる効果によって著しく遅くなるという理論 的予測があるが28), 遅延効果の定量的な予測はされておらず 実験結果を説明できるかどうかは不明である。また, trapped entanglementで形成されている網目 (NL) と比べると, 化学架橋 点が主体の網目 (NS)では網目鎖の運動性が大きく低下すると いう報告もあり ${ }^{29)}$ ， ホスト網目の運動性の低下がゲスト鎖の レプテーションに及ぼす効果も考慮すべきかもしれない.

\section{4. 網目のトポロジー制御による高伸長性および 高ダンピングゲルの創製}

\section{1 脱膨潤ゲルの高伸長特性 ${ }^{30-33)}$}

高伸長性はエラストマーの際立った特徴であるが, 破断伸 び $\left(\lambda_{\max }\right)$ が10倍を超えることはほとんどない.この経験的事実 は, 以下のように大まかに理解できる. 重合度 $N$ の本のガ ウス鎖の $\lambda_{\text {max }}$ の理論值は $N^{1 / 2}$ であり, 一本鎖の場合は長い鎖ほ

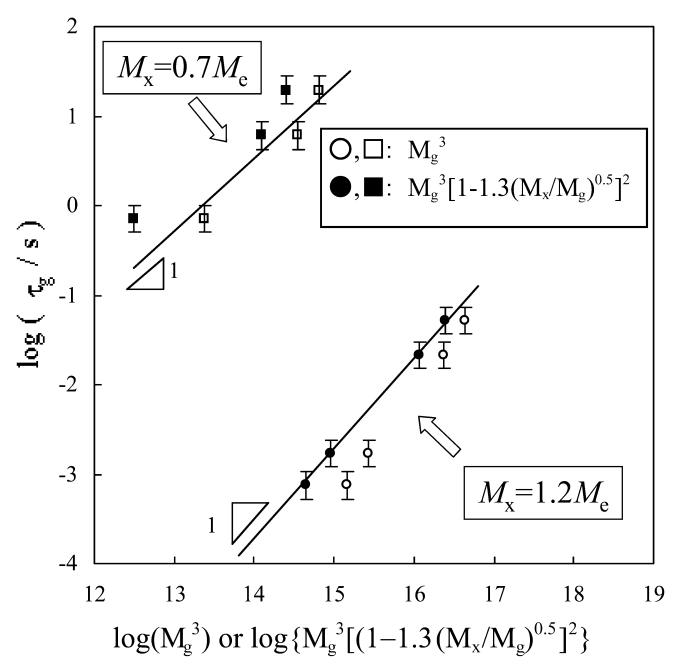

Fig. 6. Dependence of $\tau_{\mathrm{g}}$ on $M_{\mathrm{g}}$ in the end-linked PDMS networks NL and NS.
どよく伸びる. しかし，長い鎖をメルト状態で架橋したゴム では架橋時に trapped entanglementが多数形成されるので， $\lambda_{\text {max }}$ の理論值は $N^{1 / 2}$ ではなく $N_{\mathrm{e}}^{1 / 2}\left(N_{\mathrm{e}}\right.$ は $M_{\mathrm{e}}$ に相当する重合度 $)$ にな る. $N_{\mathrm{e}}$ は高分子の種類によって異なるが，典型的な值を用い ると $\lambda_{\text {max }}=4 \sim 6$ となり, 経験的事実と大きく違わない.

著者らは, 30 を超える $\lambda_{\text {max }}$ を示すシリコーンエラストマー を脱膨潤法によって作製した. ${ }^{31)}$ 脱膨潤の概念はObukhovら ${ }^{34)}$ によって理論的に提唱され，この手法によれば高伸長性を発 現するトポロジー的特徴をもつゲル網目が形成される．脱膨 潤法は，長いプレカーサ鎖を低濃度の溶液中で末端架橋し， 生成したゲルから溶媒を完全に除去する手法である．第一段 階の低濃度での架橋は trapped entanglementの数を減らすのに 有効であり, 系の絡み合い点間距離は $N_{\mathrm{e}}(\phi)=N_{\mathrm{e}}(1) \phi^{-1}$ のように 増加する ( $\phi$ は高分子鎖の体積分率)．第二段階でゲルから溶 媒を除去すると，ゲルの体積は小さくなり除去前に比べて $\phi$ 倍になる．ゲルの体積減少に伴う網目鎖の形態の縮みによっ て伸長前の網目鎖の両末端間距離 $R_{\mathrm{d}}$ が小さくなるので，鎖が 伸びきるまでの伸びが大きくなる．簡単のために脱膨潤時に アフィン変形を仮定すると, $R_{\mathrm{d}}$ は $R_{\mathrm{d}}=R(\phi) \phi^{1 / 3}$ のように減少す る. これら $2 つ の$ 効果を取り入れると, 体積分率 $\phi$ の溶液から 作製された脱膨潤ゲルの $\lambda_{\text {max }}$ の理論值は, メルト架橋の場合 よりも $\phi^{-5 / 6}$ 倍だけ向上する. 溶液が数\%の低濃度の場合, $\lambda_{\text {max }}$ の理論值は 100 に達する.

$M_{\mathrm{w}}=9.9 \times 10^{4}\left(M_{\mathrm{w}} / M_{\mathrm{n}}=1.2\right)$ のプレカーサPDMS 鎖の低濃度 溶液 $(\phi=0.1)$ から作製した脱膨潤PDMSゲルの工学応力 $\left(\sigma_{\mathrm{e}}\right)-$ 伸び曲線をFig. 7に示す. 比較のためにメルト架橋ゲル $(\phi=1)$ の結果も示す. 図中の応力は各試料のヤング率 $(E)$ で規格化さ れている. バルク架橋ゲルの $\lambda_{\text {max }}$ が約 2 であるのに対し脱膨潤 ゲルの $\lambda_{\text {max }}$ は31に達しており, 脱膨潤法が $\lambda_{\text {max }}$ の向上に効果的 であることがわかる。この脱膨潤PDMSゲルの $\lambda_{\text {max }}=31$ は, 過 去のエラストマーの $\lambda_{\text {max }}$ の報告值としては最高值と考えられ ている. ${ }^{32)}$ 図中に古典ゴム弾性論の予測 $\left(\sigma_{\mathrm{e}} / E=\left(\lambda-\lambda^{-2}\right) / 3\right)$ を示 す. 古典ゴム弾性論は絡み合い効果を無視したランダムコイ ル鎖から成る網目に対する予測であるが，脱膨潤ゲルの応力 の伸び依存性はそれよりも著しく弱い.この弱い応力の伸び 依存性は高伸長性を示す脱膨潤ゲルに特徵的であり, 後述す

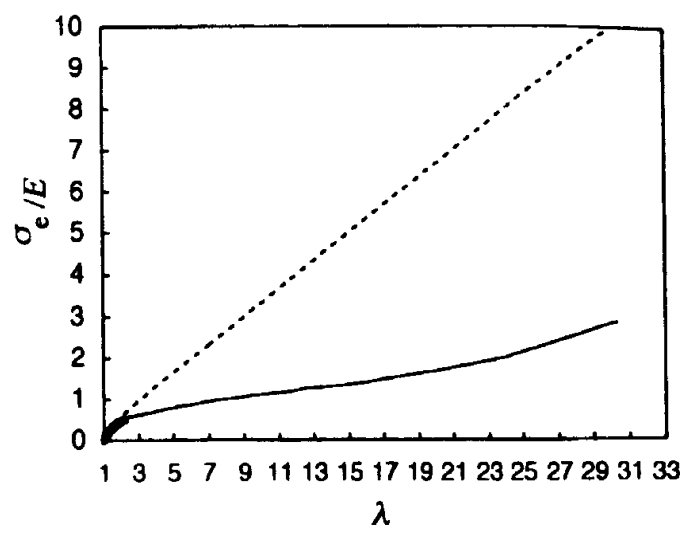

Fig. 7. Engineering stress $\left(\sigma_{\mathrm{e}}\right)$ - elongation $(\lambda)$ curves of the deswollen network prepared at $\phi=0.1$ (solid line) and the network prepared in the melt ( $\phi=1)$ (bold solid line). The dashed curve represents the prediction of classical rubber elasticity theory. The stress is reduced by initial Young's modulus $(E)$. 
るように脱膨潤時に形成される網目鎖の収縮した形態 (supercoil と呼ばれる) に起因している.また，Eの依存性も $\phi か ゙$ 低くなるほじ（脱膨潤の程度が大きくなるほど）古典ゴ 厶弾性論の予測からの逸脱が大きくなり, supercoilの形成の 影響が現れる. ${ }^{30)}$ また, supercoilの形成の効果は脱膨潤ゲルの 低温結晶化挙動にも見られる. ${ }^{35}$

Pincusの理論 36,37 によれば, フラクタル次元 $D$ の一本鎖の大 変形における $\sigma_{\mathrm{e}}$ の入依存性は

$$
\sigma_{e} \sim \lambda^{1 /(D-1)}
$$

である．高伸長性の脱膨潤ゲルは低濃度で架橋されており網 目鎖の絡み合いは少なく網目鎖間の相互作用は小さいと考 えられるので, 式(8)による実験データの解析を行った. Dが 既知であるランダムコイル鎖 $(D=2)$ から成る低濃度のゲルの $\sigma_{\mathrm{e}}$ の 依存性を調べ, 式(8)の妥当性を検討した. 低濃度溶液 $(\phi=0.25)$ から作製した架橋直後のPDMS ゲル（トルエンは PDMS $の$ 良溶媒であるが， $\phi \approx 10 \phi^{*}$ であり排除体積効果は十分 に遮蔽されている）の大変形領域での挙動は $\sigma \sim \lambda^{1.0}$ であり, 式(8)の $D=2$ の場合の予測とよく一致していた. ${ }^{31)}$

Fig. 8 に $\phi=0.15$ および $\phi=0.10$ で作製された脱膨潤PDMS攵 ルの規格化応力ー伸びデータの両対数プロットを示す. 図の 横軸の量には伸びそのものではなく, ゲルの非圧縮性による 側方収縮効果 $\left(-\lambda^{-2}\right)$ を考慮し $\left(\lambda-\lambda^{-2}\right)$ を用いている. 大変形領域 ではこの補正項は無視できるようになる $\left(\lambda-\lambda^{-2} \approx \lambda\right)$. これらの ゲルのプロットは良く一致し濃度依存性が見られないこと から, Fig. 8の応力の伸び依存性はsupercoilの網目鎖から成る 脱膨潤ゲルの典型的なものと考えてよい。 $\sigma$ の $\lambda$ 依存性は次 の3領域に分けられる: $\sigma_{\mathrm{e}} \sim\left(\lambda-\lambda^{-2}\right)^{1.0}(1<\lambda<1.6)$ (領域I); $\sigma_{\mathrm{e}} \sim \lambda^{0.46}$ $(1.6<\lambda<16)$ （領域II）; $\sigma_{\mathrm{e}} \sim \lambda^{1.0}(16<\lambda<31)$ (領域III). 領域IIおよ びIIIは, 非常に広い $\lambda$ 範囲で $\sigma_{\mathrm{e}}$ の $\lambda$ 依存性が一定のべキ乗則 に従う。領域IIのデータに式(8)を用いると $D=3.2$ となり, 同 領域はランダムコイル $(D=2)$ よりも空間的に密なコンフォ メーションの supercoilを解きほぐす過程に相当することが示 唆される. 寸なわち, 脱膨潤ゲルの非常に弱い忘力の伸び依 存性は網目鎖の収縮した形態によるものである.また, 領域 IIIは式(8)のD=2の場合に相当し, supercoilからランダムコイ ルの網目鎖の力学応答へのクロスオーバーが見られる.

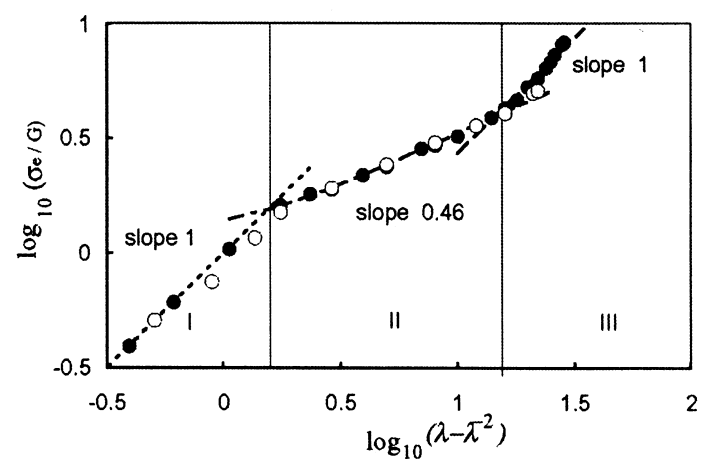

Fig. 8. The double logarithmic plots of reduced stress and $\left(\lambda-\lambda^{-2}\right)$ for the highly extensible deswollen networks prepared at $\phi=0.15$ (O) and $\phi=0.10(\bullet)$.

\section{2 ペンダント鎖を多量に含むゲルのダンピング特性 ${ }^{38,39)}$}

片末端のみに反応基を有するプレカーサ鎖と両末端に反 応基を有するプレカーサ鎖の混合物を末端架橋すると，片末 端のみが網目につながった鎖（ペンダント鎖）を多量に含む 不規則構造の網目を作製することができる．また，末端架橋 法では反応後の未反応成分の量 $\left(W_{\mathrm{sol}}\right)$ から, 生成した網目中の ペンダント鎖の割合を評価することができる．著者らは，こ の不規則網目の動的粘弾性を調ベ，ペンダント鎖が網目の粘 弾性に及ぼす影響を検討した。 ${ }^{38)}$

二種の方法(Scheme-AおよびB)を用いて，不規則網目構造 をもつPDMS ゲルを作製した． Scheme-A は，両末端反応性 PDMS(B-PDMS; $\left.M_{\mathrm{n}}=29,600\right)$ と, 片末端反応性PDMS(M-PDMS; $\left.M_{\mathrm{n}}=25,700\right)$ の混合物を3官能性架橋剤メチルトリスジメチル シロキシシランで末端架橋する方法である. Scheme-Bは, BPDMS と 3 官能性架橋剂を非化学量論比 $(r \neq 1)$ で反応させる方 法である. $r$ はB-PDMSのビニル基に対する架橋剤の $\mathrm{Si}-\mathrm{H}$ 基の モル比であり，r=1が化学量論比に相当する. B-PDMSが過

(a)

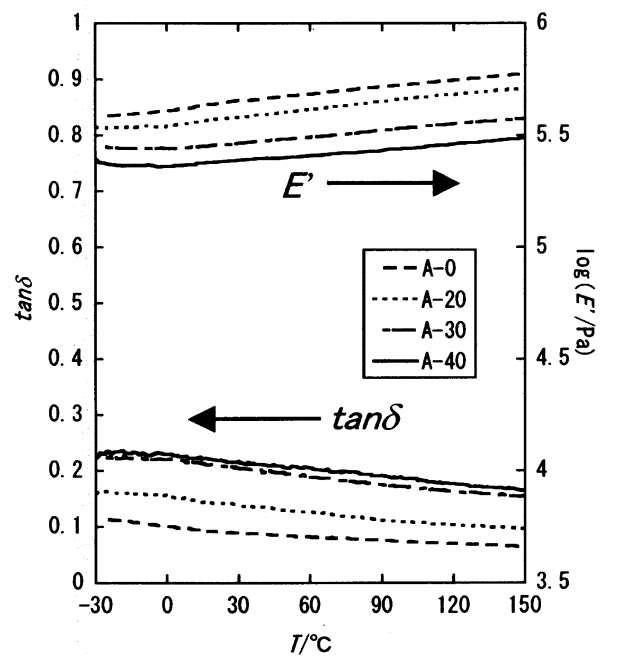

(b)

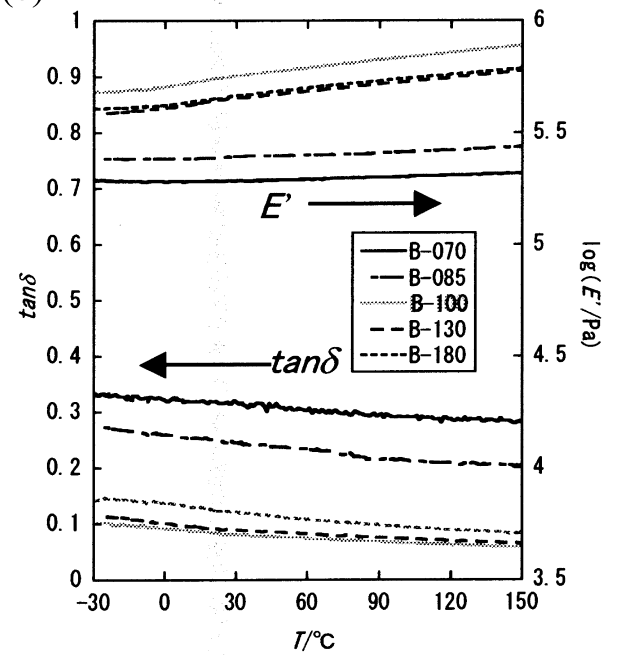

Fig. 9. Temperature dependence of $\tan \delta$ and $E^{\prime}$ for the irregular PDMS networks prepared via (a) Scheme-A and (b) Scheme-B. (a) The numeral $\mathrm{X}$ in the sample code $\mathrm{A}-\mathrm{X}$ denotes the molar content of $\mathrm{M}$ PDMS. (b) The numeral Y in the sample code B-Y strands for $r \times 100$. 
剰 $(r<1)$ あるいは架橋剤が過剰 $(r>1)$ のとき, 片末端が未反応 のB-PDMSすなわちペンダント鎖が多く生じることになる. 架橋反応終了後，未反応成分をゲル試料をトルエンで膨潤さ せることにより抽出した. 未反応成分を抽出し, 脱膨潤, 乾 燥させたゲル試料の動的粘弾性を調べた.

Fig. 9 に, Scheme-A を用いた試料(M-PDMS: 0, 20, 30, 40 mol\%) およびScheme-Bを用いた試料 $(r=0.7,0.85,1.0,1.3,1.8)$ の周波数 $10 \mathrm{~Hz}$ における $\tan \delta$ と $E^{\prime}$ の温度依存性を示寸. Scheme$\mathrm{A}$ の場合, $\tan \delta$ はペンダント鎖となるM-PDMSの仕込み量とと もに増加し， $40 \mathrm{~mol} \%$ の仕込み量ではM-PDMSを含まない場 合に比べて約2 2.5倍程度大きくなる. Scheme-Bの場合, 化学 量論比 $(r=1)$ からずれるに従って $\tan \delta$ の值は大きくなる. $r=$ 0.7 の時に最も $\tan \delta$ が大きく 0.3 を超える值となり,$r=1$ の場合 と比べて3 4倍大きくなった（用途にもよるが, $\tan \delta>0.2$ が制 振ゴム材料の指標といわれている)。また，これらのゲルの $\tan \delta$ おび $E^{\prime}$ は- $30^{\circ} \mathrm{C}$ か $150^{\circ} \mathrm{C}$ という広い温度範囲にわたっ てほぼ一定であり, 周波数依存性も小さい. 既存の制振エラ ストマーの多くは，ガラス転移のエネルギー分散を利用して いるため, 弾性率や減衰性能の温度 - 周波数依存性が非常に 大きく使用条件が限定されるという欠点がある. PDMS ゲル は-30 ${ }^{\circ} \mathrm{C}$ 以上ではゴム状態であり（結晶の融点は約 $-40^{\circ} \mathrm{C}$, ガ ラス転移温度は約 $\left.-120^{\circ} \mathrm{C}\right){ }^{35)}$ ，このゲルのダンピング特性は 構造転移によるものではなく不規則網目構造の長時間緩和 に起因している. 不規則構造の長時間緩和を利用したダンピン グは, 弾性率や減衰性能の温度・周波数依存性が小さい制振 エラストマーの作製法として有効かもしれない. また, 高分 子量の可塑剤を架橋ゴムへ導入し, 可塑剤すなわちゲスト鎖
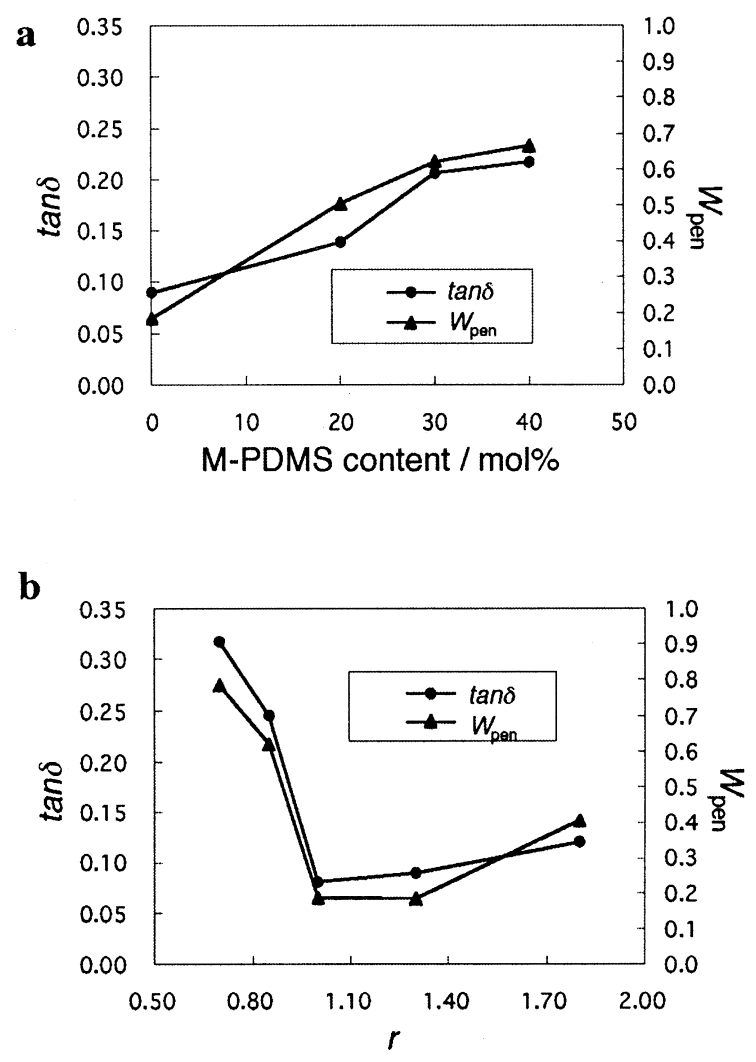

Fig. 10. The content of pendant chains and $\tan \delta$ as a function of (a) MPDMS content and (b) $r$.
の粘弾性緩和 (3.2項参照) を利用した制振エラストマーも存在 するが，用途が封入系に限定される．網目自体の不規則構造 の緩和を利用する場合, dry系として扱えるという特徴もある.

網目中のペンダント鎖の重量分率 $\left(W_{\mathrm{pen}}\right)$ は, 末端架橋による 網目形成の理論を用いて $W_{\mathrm{sol}}$ と反応条件 $(r$ おび各一次高分 子鎖の分子量)より評価される. ${ }^{3,40,41)}$ Fig. 10に各Schemeによっ て作製された試料の $W_{\text {pen }}$ と $\tan \delta$ の関係を示す. 両系ともに $\tan \delta$ は $W_{\text {pen }}$ とよく相関しており, $\tan \delta$ はペンダント鎖の量とともに 増加することがわかる. 最も大きな $\tan \delta$ を示す試料の $W_{\mathrm{pen}}$ は 約 0.8 であり, 網目中のほとんどの鎖がペンダント鎖に分類さ れる（詳細は省くが，この場合でも弾性的に有効な鎖の分率 $\left(1-W_{\text {pen }}\right)$ はゲル化すなわち無限大網目形成に必要な最小值は 上回っている). また, $\tan \delta$ は $W_{\text {pen }}$ の值に支配されており, Scheme-AとBのどちらの方法においても同様な不規則網目構 造が形成されていることがわかる。

ここでは網目構造にペンダント鎖を多量に導入している ため，単一のペンダント鎖ではなくランダムな枝分かれを持 つ巨大網目高分子の緩和挙動が現れている. $\tan \delta$ の弱い温度・ 周波数依存性から，不規則網目構造の緩和時間は長く分布が 非常に広いことがわかる．緩和機構の詳細の解明は複雑な網 目構造のために容易ではないが，この緩和の特徽は枝分かれ の形状の多様性および広いサイズ分布に起因していること は間違いない。

\section{5. ゲルの相転移現象に関する研究 ${ }^{42-51)}$}

本項にはゾルーゲル転移の研究も含まれるが，ここでは液 晶ゲルの相転移の研究について述べる.

ゲルの体積相転移現象は, わずかな環境（温度, 溶媒組成 など）の変化によって溶媒中のゲルの体積が大きく変化する 現象である，著者らは，サーモトロピック性の側鎖型液晶 ネットワーク $(\mathrm{LCN})$ を合成し, その膨潤挙動を調べ, 液晶相 転移を駆動力とした体積相転移を発見した．Fig. 11 に等方性 （非液晶性）溶媒（ジブチルフタレート）中におけるポリド メインLCNの平衡膨潤度の温度依存性を示す. ${ }^{44)}$ ゲルは等方 (I)相で膨潤しているが, 温度 $T_{\mathrm{NI}} \mathrm{G}$ でネマチック $(\mathrm{N})$ 相に転移す ると体積が不連続的に大きく減少する。また，同図に低分子

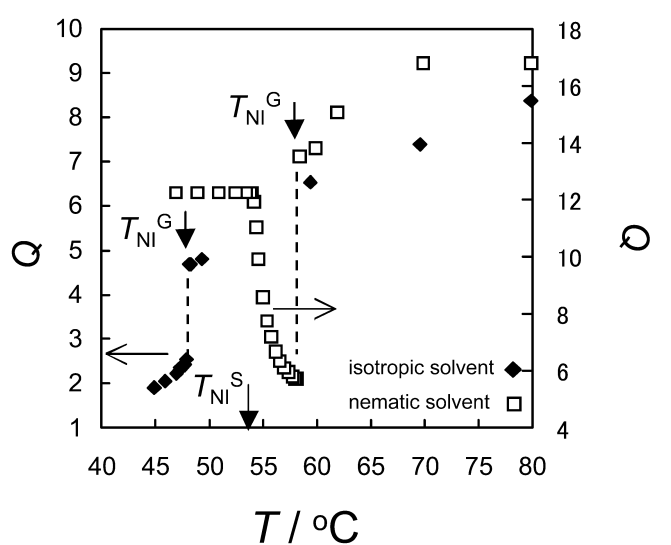

Fig. 11. Degree of equilibrium swelling as a function of temperature for the polydomain nematic networks swollen in an isotropic or nematic solvent. 
液晶溶媒中での結果も示す. ${ }^{42)}$ 液晶溶媒の場合も，ゲルのI-N 相転移に伴って不連続的な体積の減少が起きる。この場合の ゲルのN相はLCN と液晶溶媒から成る単一N相である。さら に冷却するとゲルの体積は再び増加していき，ゲル外部の純 液晶溶媒の転移温度 $T_{\mathrm{NI}}$ s 付近ではI相の膨潤度と同程度までに 回復する.ゲル外部の液晶溶媒のI-N転移では膨潤度変化に不 連続性はみられず，N相の膨潤度は温度にほとんど依存しな い. 実験結果は平均場理論によって熱力学的に説明でき, LCN の膨潤挙動は系の構成分子の配向度によって支配されてい

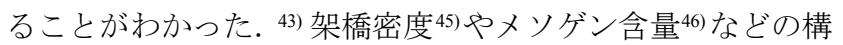
造パラメータが体積相転移挙動に与える影響も明らかにし た.さらに，液晶が巨視的な配向を有するモノドメイン液晶 ゲルを作製し体積相転移挙動を調べた。モノドメイン系では ネマチック相で形状異方性が現れること, および相転移が連 続的に起こることを明らかにし, ポリドメイン系の体積相転 移挙動との差異を明らかにした. ${ }^{48,49)}$ また, 液晶ゲルの体積 相転移のダイナミクスでは，液晶相転移過程とゲルの拡散が 結合することにより，通常の（非液晶性）ゲルの体積相転移 ではみられない特徴的なダイナミクスが現れることがわ かった. ${ }^{47)}$

\section{謝 辞}

本研究を遂行するにあたり, 粎谷信三教授 (京都大学化学 研究所），㴰川敏算教授（京都大学大学院工学研究科）から 頂いた多数の貴重な御助言に厚く感謝いたします。また，ゲ ルの研究に取り組むきっかけを下さり御指導頂いた升田利 史郎先生（京都大学名誉教授）に心から感謝いたします. 本 研究は, 京都大学大学院工学研究科の大学院生の方々と共に 行った研究であり, 河村幸伸博士（現金沢大学），横山景介 氏 (現日本精工(株), 新井裕子博士 (現メルク(株), 三木孝之 氏（現住友ゴム工業(株)）に深く感謝いたします。

\section{REFERENCES}

1) Gottlieb M, Macosko CW, Benjamin GS, Meyers KO, Merril EW, Macromolecules, 14, 1039 (1981).

2) Mark JE, Adv Polym Sci, 44, 1 (1982).

3) Patel SK, Malone C, Cohen C, Gillmor JR, Colby RH, Macromolecules, 25, 5241 (1992).

4) Kawamura T, Urayama K, Kohjiya S, Macromolecules, 34, 8252 (2001).

5) Urayama K, Kawamura T, Kohjiya S, Macromolecuels, 34, 8261 (2001).

6) Kawamura T, Urayama K, Kohjiya S, J Polym Sci, Part B, Polym Phys, 40, 2780 (2003).

7) Urayama K, Kawamura T, Kohjiya S, J Chem Phys, 118, 5658 (2002).

8) Kawamura T, Urayama K, Kohjiya S, Nihon Reoroji Gakkaishi, 31, 213 (2003).

9) Treloar LRG, "The Physics of Rubber Elasticity", Oxford University Press, Oxford, 1975.

10) Kawabata S, Nihon Reoroji Gakkaishi, 12, 69 (1984).

11) Fukahori Y, Seki W, Polymer, 33, 502 (1992).
12) Urayama K, Kohjiya, S, J Chem Phys, 104, 3352 (1996).

13) Urayama K, Kawamura T, Kohjiya S, J Chem Phys, 105, 4833 (1996).

14) Rivlin RS, Saunders DW, Philos Trans $R$ Soc, A243, 251 (1951).

15) Gaylord RJ, Douglas JF, Polym Bull, 23, 529 (1990).

16) Rubinstein M, Panyukov S, Macromolecules, 30, 8036 (1997).

17) Edwards SF, Vilgis TA, Polymer, 27, 483 (1986).

18) Kloczkouwski A, Mark JE, Erman B, Macromolecules, 28, 5089 (1995).

19) Kaliske M, Heinrich G, Rubber Chem Technol, 72, 602 (1999).

20) Vilgis TA, Erman B, Macromolecules, 26, 6657 (1993).

21) Urayama K, Yokoyama K, Kohjiya S, Macromolecules, 34, 4513 (2001).

22) Doi M, Edwards SF, "The Theory of Polymer Dynamics", Clarendon Press, Oxford, 1986.

23) Kramer O, Greco R, Neira RA, Ferry JD, J Polym Sci, Polym Phys Ed, 12, 2361 (1974).

24) Grannik S, Pedersen S, Nelb GW, Ferry JD, J Polym Sci, Polym Phys Ed, 19, 1745 (1981).

25) Poh B, Adachi K, Kotaka T, Macromolecules, 20, 2569 (1987).

26) Ndoni S, Vorup A, Kramer O, Macromolecules, 31, 3353 (1998).

27) de Gennes PG, Macromolecules, 19, 1245 (1986).

28) Muthkumar M, Baumgartner A, Macromolecules, 22, 1941 (1989).

29) Callaghan PT, Samulski ET, Macromolecules, 33, 3795 (2000).

30) Urayama K, Kohjiya S, Polymer, 38, 955 (1997).

31) Urayama K, Kohjiya S, Eur Phys J B, 2, 75 (1998).

32) Urayama K, Kobunshi, 47, 572 (1998).

33) Urayama K, Nippon Gomu Kyokaishi, 74, 347 (2001).

34) Obukhov SP, Rubinstein M, Colby RH, Macromolecules, 27, 3191 (1994).

35) Urayama K, Yokoyama K, Kohjiya S, Polymer, 41, 3273 (2000).

36) Pincus P, Macromolecules, 9, 386 (1976).

37) de Gennes PG, "Scaling Concepts in Polymer Physics", Cornell Univ. Press, 1979.

38) Urayama K, Miki T, Takigawa T, Kohjiya S, Chem Mat, 16, 173 (2004).

39) Urayama K, Takigawa T, Kohjiya S, Settyaku, 47, 374 (2003).

40) Miller DR, Macosko CW, Macromolecules, 9, 206 (1976).

41) Bibbó M, Vallés EM, Macromolecules, 17, 360 (1984).

42) Urayama K, Okuno Y, Kawamura T, Kohjiya S, Macromolecules, 35, 4567 (2002).

43) Urayama K, Okuno Y, Nakao T, Kohjiya S, J Chem Phys, 118, 2903 (2003).

44) Urayama K, Okuno Y, Kohjiya S, Macromolecules, 36, 6229 (2003).

45) Okuno Y, Urayama K, Kohjiya S, J Chem Phys, 118, 9854 (2003). 
46) Arai YO, Urayama K, Kohjiya S, Polymer, 45, 5127 (2004).

47) Urayama K, Arai YO, Takigawa T, Macromolecules, 37, 6161 (2004).

48) Urayama K, Arai YO, Takigawa T, Macromolecules, 38, 3469 (2005).
49) Urayama K, Arai YO, Takigawa T, Macromolecules, 38, 5721 (2005).

50) Urayama K, Takigawa T, Kobunshi, 54, 470 (2005).

51) Urayama K, Arai YO, Takigawa T, Ekisyo, 9, 168 (2005). 